\title{
Penerapan Model Single Sign-On dengan Sistem Front Office dan Layanan pada Sistem E-Bengkel Terintegrasi
}

\author{
Oka Sudana $^{\# 1}$, Angga Kusuma ${ }^{\# 2}$, Sunia Raharja ${ }^{\# 3}$, Ayu Wirdiani ${ }^{\# 4}$

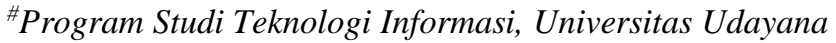 \\ Jl. Raya Kampus Udayana, Jimbaran, Kuta Selatan, Badung, Bali 80361 \\ 1agungokas@unud.ac.id \\ ${ }^{2}$ gedeanggakpegmail. com \\ ${ }^{3}$ sunia.raharja@unud.ac.id \\ ${ }^{4}$ ayuwirdiani@unud.ac.id
}

\begin{abstract}
Abstrak - Bengkel kendaraan sebagai usaha layanan jasa yang banyak ditekuni oleh masyarakat kecil sebagai mata pencaharian utama. Saat perkembangan teknologi informasi yang sangat pesat, masih banyak usaha bengkel kendaraan bermotor yang menerapkan tata Kelola secara konvensional. Tata kelola secara konvensional berisiko sangat rawan terjadi kehilangan dan kerusakan data yang menyebabkan kerugian pada perusahaan. Penelitian ini berfokus pada pengembangan Sistem E-Bengkel terintegrasi berbasis web untuk memperbaiki tata kelola manual pada Bagian Front Office dan Bagian Layanan bengkel konvensional. Bagian Front Office pada bengkel merupakan bagian yang menangani proses pendaftaran pelanggan, penjualan spare part, dan check-in service. Bagian layanan pada bengkel merupakan bagian yang menangani proses penerimaan service dan pencatatan pengerjaan service kendaraan. Hasil dari sistem informasi manajemen ini yaitu berupa aplikasi berbasis web yang sesuai dengan proses bisnis Front Office dan layanan suatu bengkel kendaraan. Sistem ini menerapkan model Single Sign-On (SSO) sebagai model manajemen satu gerbang masuk untuk semua modul, manajemen session, serta manajemen semua hak akses pengguna. Model Multi-Channel Access (MCA) dipergunakan untuk memperkaya dan mempermudah akses informasi ke pemilik, pelanggan dan pegawai. Implementasi sistem berbasis komputer dengan Model SSO dan MCA diharapkan mampu meningkatkan pelayanan dan peluang bisnis dari Usaha Kecil Bengkel.
\end{abstract}

Kata kunci- E-Bengkel, Single Sign-On (SSO), MultiChannel Access (MCA), Sistem Front Office, Sistem Layanan.

Abstract - Vehicle workshops are service businesses that mostly occupied by small communities as their main livelihood. When the development of information technology is very rapid, there are still many motor vehicle repair businesses that apply conventional systems. Conventional systems had a risk of loss and damage data that causes losses to the company. This research focuses on the development of an integrated web-based workshop system (E-Bengkel). These systems will improve manual systems in the front office and conventional workshop service. The front office at the workshop is the part that handles the customer registration process, spare part sales, and check-in service. The service department at the workshop is the part that handles the process of registration, reservation and recording vehicle service work. The results of this management information system are a web-based application that accordance with the front office business processes and services of a vehicle repair shop. This system applies a single sign-on (SSO) mode.

Keywords - E-Bengkel, Single Sign-On (SSO), MultiChannel Access (MCA), Front Office System, Service Vehicle System.

\section{PEndahuluan}

Perkembangan jumlah kendaraan bermotor dari tahun ke tahun selalu mengalami peningkatan. Menurut Badan Pusat Statistik Republik Indonesia data kendaraan pada Tahun 2019 mencapai 133.617.012 juta unit kendaraan dengan rincian 15.592.419 juta untuk mobil penumpang, 231.569 ribu untuk mobil bis, 5.021.888 juta untuk mobil barang, 112.771.136 juta jumlah sepeda motor [1]. Seiring dengan bertambahnya jumlah unit kendaraan tersebut, usaha bengkel merupakan peluang bisnis yang sangat menjanjikan. Tata kelola usaha bengkel kendaraan sudah semestinya dilakukan modernisasi. Bengkel kendaraan adalah suatu badan usaha yang bergerak di bidang penjualan dan pelayanan perbaikan kendaraan bermotor. Tata kelola bengkel kendaraan yang masih konvensional pada era teknologi seperti sekarang menimbulkan beberapa permasalahan seperti tidak efisiensi waktu dalam mengolah data dan sangat rawan terjadi kehilangan serta kerusakan data yang menyebabkan kerugian pada bengkel kendaraan. Peluang peningkatan kualitas layanan dan peningkatan peluang pasar juga relatif terbatas jika masih memakai model konvensional. Melihat permasalahan tersebut perlu diciptakan suatu sistem informasi yang dapat 
dikembangkan untuk mendapatkan informasi yang cepat dan saling terintegrasi dalam menunjang dan mendukung proses bisnis Front Office dan layanan untuk proses pengambilan keputusan pada suatu bengkel kendaraan. Suatu usaha bengkel kendaraan memiliki beberapa bagian untuk mendukung proses bisnisnya seperti Modul Front Office, Layanan, Inventory, dan lain sebagainya. Oleh sebab itu penerapan Model Single Sign-On (SSO) diperlukan untuk mengelola hak akses pengguna pada sistem yang saling terintegrasi. Single Sign-On adalah sistem autentikasi yang mengizinkan pengguna atau user untuk mengakses berbagai modul aplikasi dengan menggunakan satu credential tanpa harus login di masingmasing aplikasi [2]. Oleh sebab itu, penelitian ini berfokus untuk bagaimana melakukan penerapan Model SSO dengan Sistem Front Office dan Sistem Layanan pada suatu bengkel kendaraan, dengan dukungan Multi-Channel Access (MCA) sebagai alternatif komunikasi Pemilik dan Karyawan.

Beberapa penelitian pernah dilakukan mengenai penerapan SSO. Penelitian terkait SSO yang dilakukan oleh Guntoro, dkk [3], melakukan perancangan sistem Single Sign-On dengan menggunakan autentikasi gambar. Hasil dari penelitian ini yaitu berupa model autentikasi login menggunakan gambar dengan metode least significant bit. Penelitian lainnya dilakukan oleh Musliyana, dkk [4], melakukan peningkatan sistem keamanan pada Single Sign-On dengan menggunakan Algoritma AES dan one time password (OTP) pada SSO Universitas Ubudiyah Indonesia. Hasil penelitian yang didapatkan yaitu penerapan Algoritma AES dengan pembangkit kunci dinamis pada autentikasi SSO UUI dapat mencegah serangan dictionary attacks dan rainbow tables. Penelitian oleh Putri, dkk [5], melakukan optimasi Single Sign-On untuk peningkatan pada sistem keamanan OJRS+. Metode yang digunakan pada penelitian ini yaitu Metode Mind Mapping. Hasil yang didapat yaitu penerapan Single SignOn dapat memberikan kenyamanan dan keamanan dalam mengakses sistem web Perguruan Tinggi Raharja. Penelitian oleh Darma Udayana, dkk [6], melakukan implementasi dan menganalisis Single Sign-On pada sistem informasi Universitas Udayana. Hasil dari penelitian tersebut yaitu sistem SSO yang diintegrasikan dengan sistem informasi Universitas Udayana telah mampu menangani proses autentikasi secara terpusat dan dapat diintegrasikan dengan aplikasi yang tidak menggunakan Lightweight Directory Access Protocol (LDAP) sebagai manajemen pengguna sistem.

Beberapa penelitian pernah dilakukan mengenai sistem informasi manajemen bengkel. Penelitian oleh Audrilia, dkk [7], melakukan penelitian sistem informasi manajemen bengkel untuk mengatasi permasalahan pada Bengkel Anugrah yang melakukan proses bisnis secara manual. Sistem informasi pada penelitian ini dapat menampilkan data service pelanggan yang telah di-input oleh admin. Pengujian sistem menggunakan ISO 25010 dengan aspek functionality, efficiency, dan realibility. Hasil dari pengujian yang dilakukan dengan melibatkan tujuh responden bahwa kesimpulan kualitas kelayakan perangkat lunak yang dihasilkan memiliki persentase keberhasilan dengan total rata-rata 92,38\%. Penelitian oleh Salim RR [8], berfokus pada sistem informasi manajemen bengkel untuk mengelola transaksi sehari-hari pada usaha bengkel yang belum menggunakan sistem informasi. Metodologi penelitian yang digunakan dalam pengembangan sistem informasi ini adalah Sistem Development Life Cycle (SDLC). Hasil dari penelitian tersebut yaitu sistem informasi yang dapat membantu bengkel dalam mengelola transaksi sehari-hari, seperti kegiatan pembelian, persediaan, penjualan dan service. Penelitian oleh Winardi, dkk [9], berfokus pada pembuatan sistem informasi untuk bengkel CV. Anugrah yang masih dilakukan secara manual. Metode penelitian yang digunakan yaitu metode waterfall. Hasil dari penelitian ini yaitu sistem infromasi dengan proses transaksi penjualan, pelayanan service, proses pemesanan, pembelian dan penerimaan barang menjadi terkomputerisasi. Penelitian oleh Widhiananda [10], bertujuan untuk merancang sistem informasi yang diharapkan dapat memecahkan permasalahan reservasi manual bengkel yang dapat menjadi masalah ketika jumlah antrean pelanggan cukup banyak. Penelitian ini menghasilkan sebuah aplikasi reservasi service untuk bengkel sepeda motor berbasis web berupa perangkat lunak yang dapat dijalankan melalui browser internet. Penelitian oleh Githa, dkk [11], berfokus pada memberikan informasi tentang lokasi dan rute menuju Bengkel Vespa di Denpasar. Perancangan sistem diawali dengan menganalisis kebutuhan sistem, kemudian membuat rancangan sistem menggunakan DFD, dan membuat rancangan basis data sesuai dengan keperluan sistem, serta membuat rancangan antarmuka sistem.

Berdasarkan latar belakang dan beberapa referensi penelitian diatas, masih tidak ada penelitian terdahulu yang membahas secara khusus mengenai penerapan Model Single Sign-On pada suatu sistem informasi manajemen bengkel kendaraaan, khususnya integrasi Model SSO dengan Modul Front Office dan Modul Layanan yang didukung oleh Konsep dan Teknologi MCA. Integrasi Model SSO dengan Modul Front Office dan Layanan diperlukan untuk dapat melakukan autentikasi, otorisasi, dan manajemen data pengguna pada Aplikasi E-Bengkel Terintegrasi.

Oleh sebab itu, penelitian ini bertujuan untuk membangun sistem informasi manajemen bengkel berbasis web app dengan penerapan Model Single Sign-On yang berfokus pada proses bisnis Front Office dan Layanan suatu bengkel kendaraan. Sistem Front Office pada bengkel merupakan bagian yang menangani manajemen data pelanggan bengkel, proses penjualan spare part, pencatatan order service sampai pada tahap pembuatan invoice spare part, check-in service, pembuatan work order service. Sistem Layanan pada bengkel merupakan bagian yang menangani proses penerimaan dan pengerjaan service kendaraan pelanggan. 


\section{METODE}

Bagian metode memaparkan mengenai metodologi penelitian, gambaran umum sistem, konsep penerapan Single Sign-On, dan perancangan basis data dalam melakukan penelitian Model Single Sign-On dengan Sistem Front Office dan Sistem Layanan pada Sistem EBengkel Terintegrasi.

\section{A. Metodologi Penelitian}

Metodologi penelitian yang digunakan pada penelitian Penerapan Model Single Sign-On dengan Sistem Front Office dan Sistem Layanan pada Sistem E-Bengkel Terintegrasi yaitu menggunakan pengembangan SDLC (Sistem Development Life Cycle) dengan Metode Waterfall. Metodologi pengembangan sistem adalah prosedur yang digunakan untuk mengembangkan sistem informasi dalam menyelesaikan masalah dalam suatu organisasi [12].

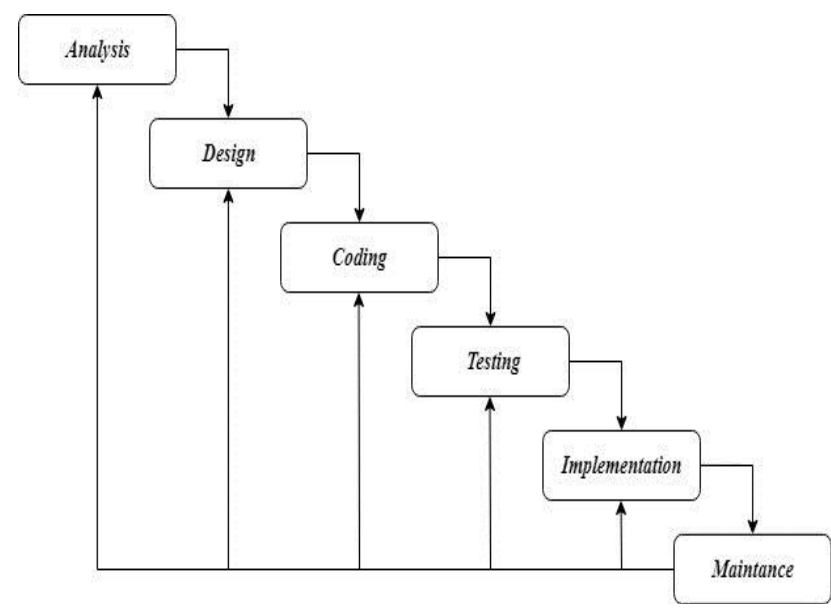

Gambar 1. Metode waterfall

Gambar 1 merupakan tahapan pada Metode SDLC (Sistem Development Life Cycle) dengan menggunakan Model Waterfall. Proses analysis dilakukan berdasarkan data yang telah dikumpulkan pada tahap sebelumnya [13] yaitu dengan dilakukan wawancara pada narasumber pemilik usaha bengkel kendaraan untuk mengetahui proses bisnis pada suatu bengkel kendaraan. Tahap Design dilakukan proses design gambaran umum, physical data model (PDM) untuk basis data Sistem Informasi Manajemen Bengkel Kendaraan, serta design antar muka yang baik agar pengembangan sistem menjadi sederhana dan user friendly [14]. Tahap Coding yaitu dilakukan pembuatan script program menggunakan Tools Visual Studio Code dengan Bahasa HTML, CSS, Javascript, PHP, serta menggunakan MySQL sebagai DBMS (Database Management Sistem). Tahap Pengujian (testing) yaitu dilakukan pengujian terhadap sistem yang telah dibuat menggunakan Metode Black-Box Testing sebelum aplikasi di-launching. Black-Box Testing berfokus pada pengujian fungsional pada suatu sistem informasi [15]. Black-box merupakan salah satu teknik pengujian perangkat lunak yang berfokus pada memeriksa fungsional dari perangkat lunak dengan melakukan pengamatan hasil eksekusi data uji [16]. Black-box testing dilakukan dengan cara menguji input dan output pada perangkat lunak tanpa melihat kode program perangkat lunak. Tahap Implementasi yaitu tahapan launching aplikasi setelah dilakukan pengujian. Tahapan terakhir yaitu tahapan maintenance yang digunakan untuk perawatan sistem apabila butuh perbaikan akibat error yang belum terdeteksi.

\section{B. Gambaran Umum Sistem}

Entitas yang terlibat pada penelitian ini yaitu Customer, Service Advisor, Front Office, Mekanik, Service Instructor, Point of Sales, Single Sign-On, dan Pemilik Bengkel. Semua data yang dibutuhkan oleh sistem akan disimpan pada basis data. Gambaran umum pada penelitian ini dapat dilihat pada Gambar 2 berikut.

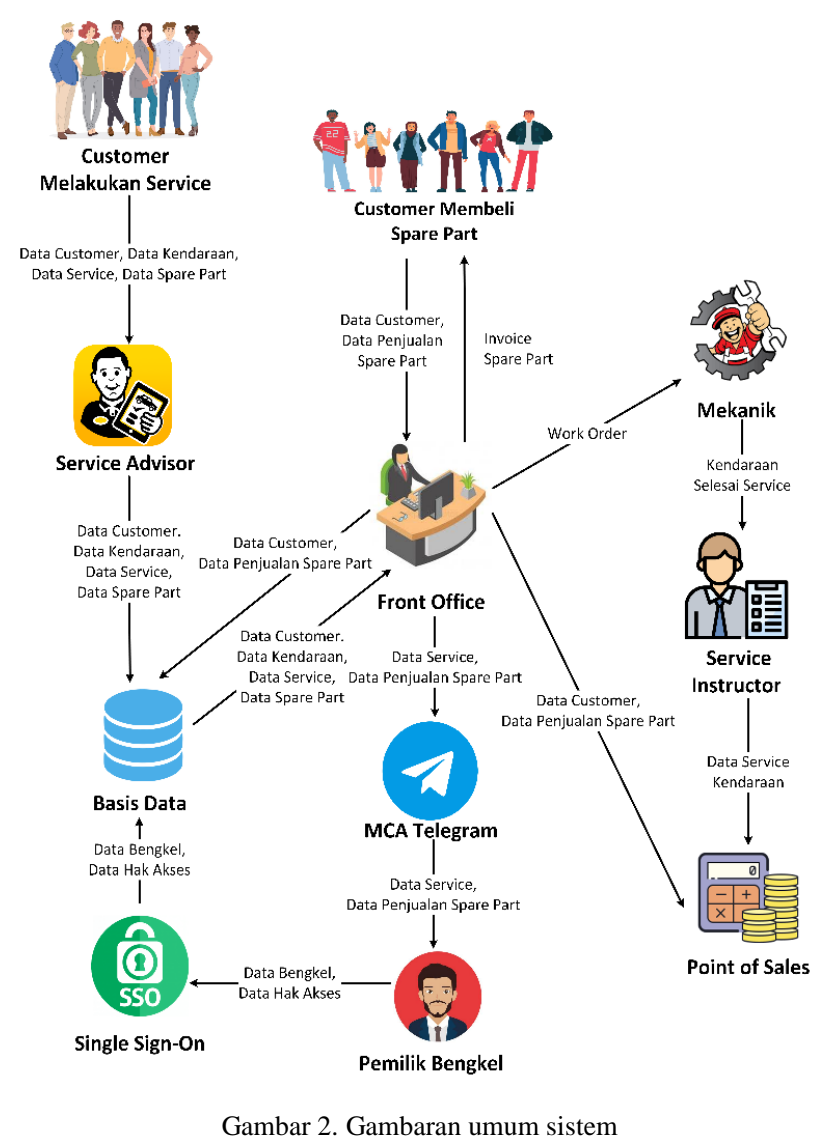

Gambar 2 merupakan gambaran umum dari penelitian Penerapan Model Single Sign-On dengan Modul Front Office dan Sistem Layanan pada Sistem E-Bengkel Terintegrasi. Alur dari sistem ini yaitu customer yang ingin melakukan service akan langsung dilayani oleh pegawai Service Advisor untuk memberikan data customer, data kendaraan, data service, dan data spare part. Data yang didapat oleh Service Advisor akan disimpan di database dan diteruskan ke bagian Front Office untuk dilakukan check-in service kendaraan. Admin Front Office selanjutnya mencetak work order dan dapat diteruskan ke bagian mekanik untuk dilakukan pengerjaan service. Data kendaraan yang telah selesai di-service diserahkan dari 
mekanik ke pegawai Service Instructor untuk selanjutnya data service kendaraan tersebut diberikan ke Point of Sales untuk dilakukan pembayaran. Customer yang ingin melakukan pembelian spare part saja dapat langsung ke bagian Front Office untuk memberikan data customer, dan data penjualan spare part. Admin Front Office selanjutnya melakukan cetak invoice spare part untuk diberikan ke customer. Data penjualan spare part diteruskan dari bagian Front Office ke bagian Point of Sales untuk dilakukan pembayaran. Data service dan data spare part dikirimkan oleh MCA Telegram ke Pemilik Bengkel dalam bentuk notifikasi Telegram.

\section{Konsep Penerapan Model Single Sign-On}

Single Sign-On bertujuan untuk dapat mengakses keseluruhan sumber daya hanya dengan satu kali login [17]. Konsep Model Single Sign-On pada penelitian ini yaitu dapat melakukan autentikasi, otorisasi, dan manajemen data pengguna. Autentikasi untuk melakukan validasi credentials (username dan password) pengguna dan menetapkan identitas pengguna. Otorisasi untuk melakukan pembatasan hak akses pada pengguna. Manajemen pengguna untuk melakukan administrasi (pembuatan, penghapusan, pembaruan) akun pengguna. Penerapan model Single Sign-On digambarkan dalam bentuk flowchart berikut.

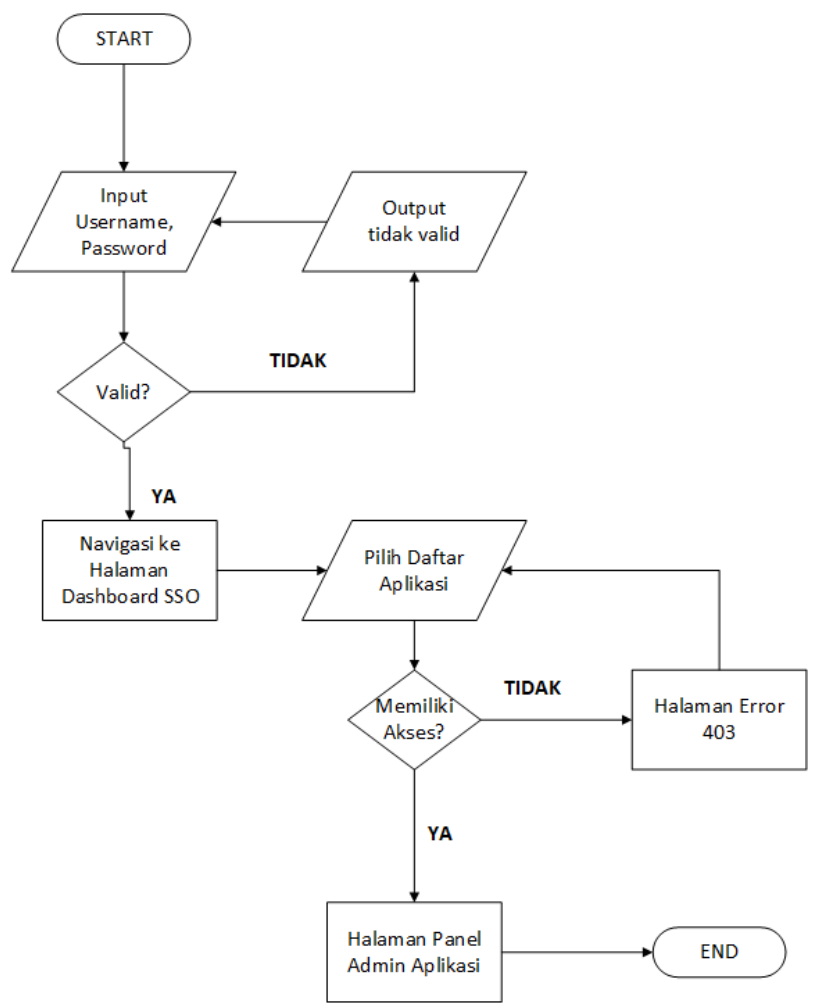

Gambar 3. Flowchart single sign-on

Gambar 3 merupakan Flowchart Single Sign-On. Alur dari Single Sign-On pada penelitian ini yaitu pertama pengguna melakukan input username dan password. Apabila username dan password valid terdaftar pada basis data maka diteruskan ke halaman Dashboard Single SignOn, apabila tidak valid maka sistem memberikan output pemberitahuan tidak valid. Pengguna yang berhasil login selanjutnya dapat memilih daftar aplikasi yang terdaftar pada Dashboard Single Sign-On. Apabila pengguna memiliki akses ke aplikasi maka akan diteruskan ke halaman panel admin aplikasi, apabila tidak memiliki akses maka sistem akan mengarahkan ke halaman eror 403.

\section{Perancangan Basis Data}

Perancangan basis data pada Penerapan Model Single Sign-On dengan Sistem Front Office dan Sistem Layanan pada Sistem E-Bengkel Terintegrasi ini menggunakan physical data model (PDM). Physical data model menunjukkan tempat penyimpanan data ketika sistem berjalan [18].

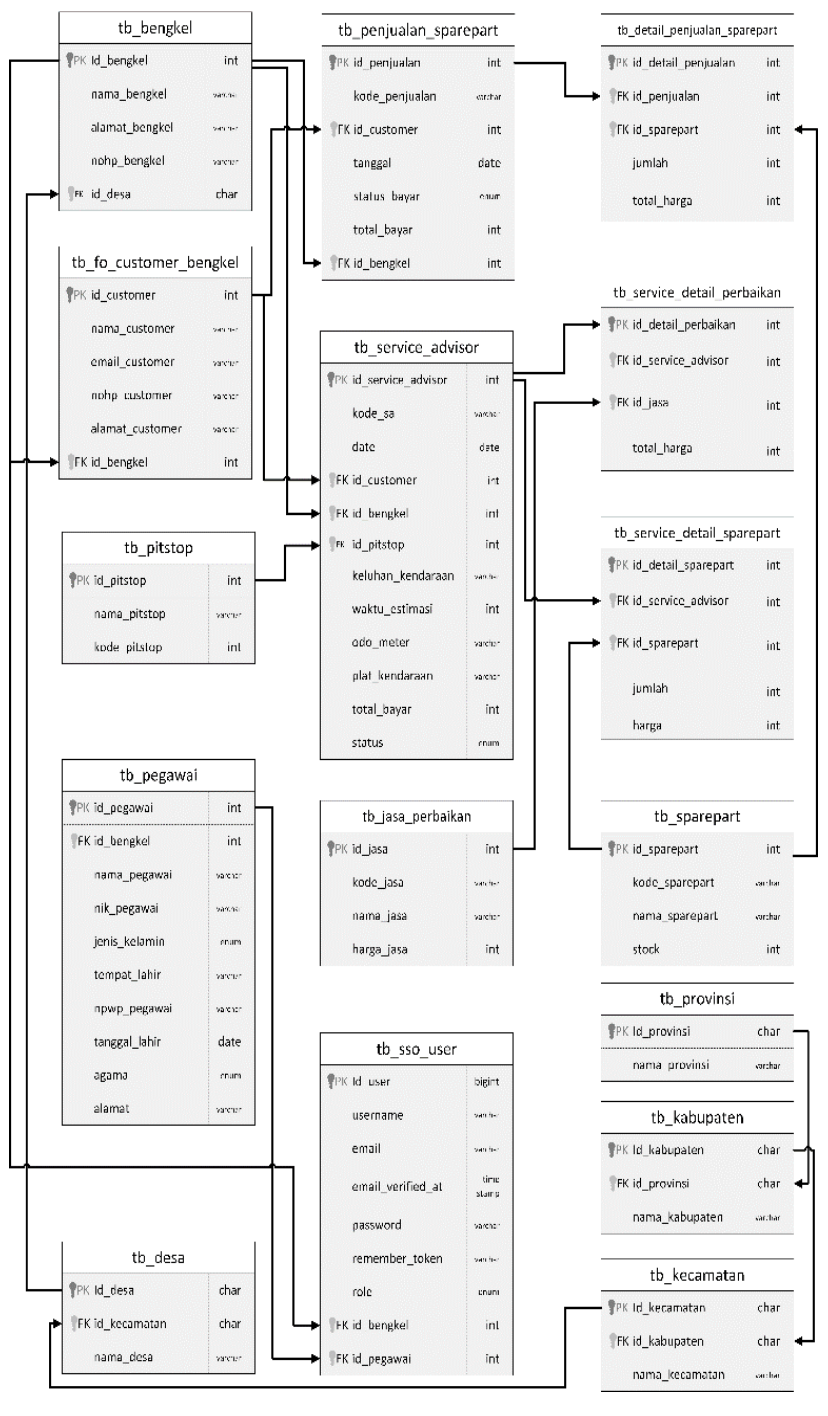

Gambar 4. Rancangan basis data

Gambar 4 menggambarkan rancangan basis data pada penelitian ini. Tabel pada gambar PDM tersebut yaitu terdapat tb_bengkel, tb_customer_bengkel, tb_penjualan_sparepart, tb_detail_ penjualan_sparepart, tb_sparepart, 
tb_service_detail_perbaikan, tb_service_detail_sparepart, tb_jasa_perbaikan, tb_pitstop, tb_pegawai, tb_sso_user, tb_provinsi, tb_kabupaten, tb_kecamatan, dan tb_desa. Setiap tabel memiliki data attribute, tipe data, dan primary key serta foreign key untuk mengetahui relasi antara tabel. Fungsi-fungsi dari tabel yang digunakan dalam perancangan basis data dapat dilihat pada tabel berikut.

TABEL I

FUNGSI TABEL

\begin{tabular}{|c|c|c|}
\hline No & Tabel & Fungsi \\
\hline 1 & Bengkel & Menyimpan data bengkel kendaraan \\
\hline 2 & Customer Bengkel & $\begin{array}{l}\text { Menyimpan data pelanggan yang } \\
\text { pernah berkunjung ke bengkel }\end{array}$ \\
\hline 3 & Penjualan Spare Part & $\begin{array}{l}\text { Menyimpan data penjualan spare } \\
\text { part pada bengkel }\end{array}$ \\
\hline 4 & Detail Penjualan & $\begin{array}{l}\text { Menyimpan jumlah spare part yang } \\
\text { dibeli oleh } \text { customer }\end{array}$ \\
\hline 5 & Spare Part & $\begin{array}{l}\text { Menyimpan data suku cadang yang } \\
\text { terdapat pada bengkel }\end{array}$ \\
\hline 6 & Service Advisor & $\begin{array}{l}\text { Menyimpan data pelanggan yang } \\
\text { melakukan service }\end{array}$ \\
\hline 7 & Detail Spare Part & $\begin{array}{l}\text { Menyimpan data jumlah spare part } \\
\text { yang digunakan untuk service }\end{array}$ \\
\hline 8 & Detail Jasa Perbaikan & $\begin{array}{l}\text { Menyimpan data jasa perbaikan } \\
\text { yang digunkan untuk service } \\
\text { kendaraan }\end{array}$ \\
\hline 9 & Jasa Perbaikan & $\begin{array}{l}\text { Menyimpan data jasa perbaikan } \\
\text { yang dapat dilayani oleh bengkel }\end{array}$ \\
\hline 10 & Pit Stop & $\begin{array}{l}\text { Menyimpan data pit stop yang } \\
\text { terdapat pada bengkel kendaraan }\end{array}$ \\
\hline 11 & Pegawai & $\begin{array}{l}\text { Menyimpan data pegawai yang } \\
\text { terdapat pada suatu bengkel } \\
\text { kendaraan }\end{array}$ \\
\hline 12 & User SSO & $\begin{array}{l}\text { Menyimpan data pengguna yang } \\
\text { memiliki hak akses pada Sistem E- } \\
\text { Bengkel terintegrasi }\end{array}$ \\
\hline 13 & Provinsi & $\begin{array}{l}\text { Menyimpan data provinsi seluruh } \\
\text { Indonesia }\end{array}$ \\
\hline 14 & Kabupaten & $\begin{array}{l}\text { Menyimpan data kabupaten seluruh } \\
\text { Indonesia }\end{array}$ \\
\hline 15 & Kecamatan & $\begin{array}{l}\text { Menyimpan data kecamatan seluruh } \\
\text { Indonesia }\end{array}$ \\
\hline 16 & Desa & $\begin{array}{l}\text { Menyimpan data desa seluruh } \\
\text { Indonesia }\end{array}$ \\
\hline
\end{tabular}

\section{HASIL DAN PEMBAHASAN}

Hasil dan pembahasan pada penelitian Penerapan Model Single Sign-On dengan Modul Front Office dan Modul Layanan pada Sistem E-Bengkel Terintegrasi ini yaitu berupa tampilan sistem dan pengujian sistem menggunakan metode black-box testing.

\section{A. Tampilan Sistem}

Tampilan sistem pada penelitian ini yaitu berupa tampilan halaman login, halaman register, manajemen data pengguna, tampilan tambah hak akses pengguna, tampilan error 403 hak akses ditolak, tampilan tambah hak akses pengguna, formular penerimaan service, tampilan check-in service, tampilan work order service, tampilan pengerjaan service, formulir penjualan spare part, invoice spare part, dan tampilan manajemen data customer. Tampilan sistem ini dapat dilihat pada gambar-gambar berikut.

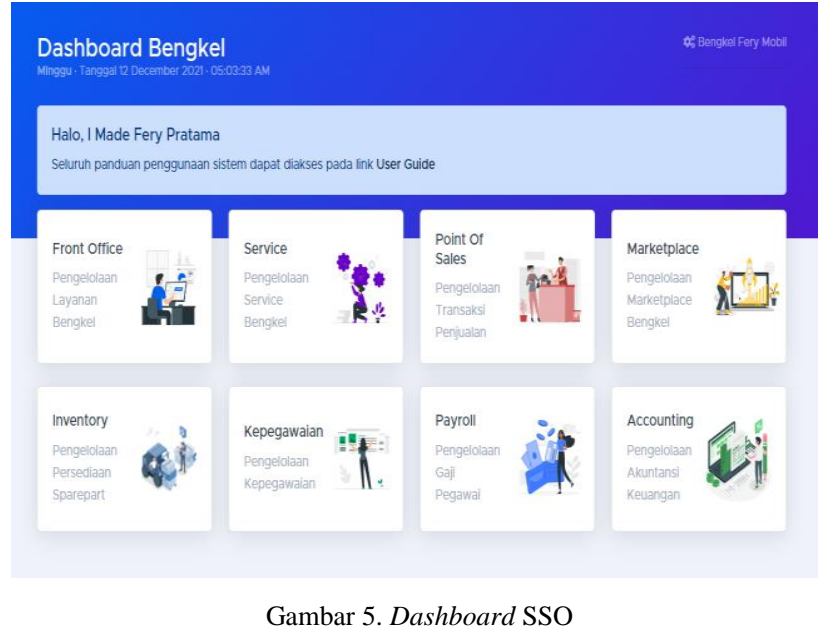

Gambar 5 merupakan manajemen dashboard SSO. Pengguna dapat melakukan akses setiap aplikasi yang terdapat pada Aplikasi E-Bengkel Terintegrasi sesuai dengan hak akses yang dimiliki.

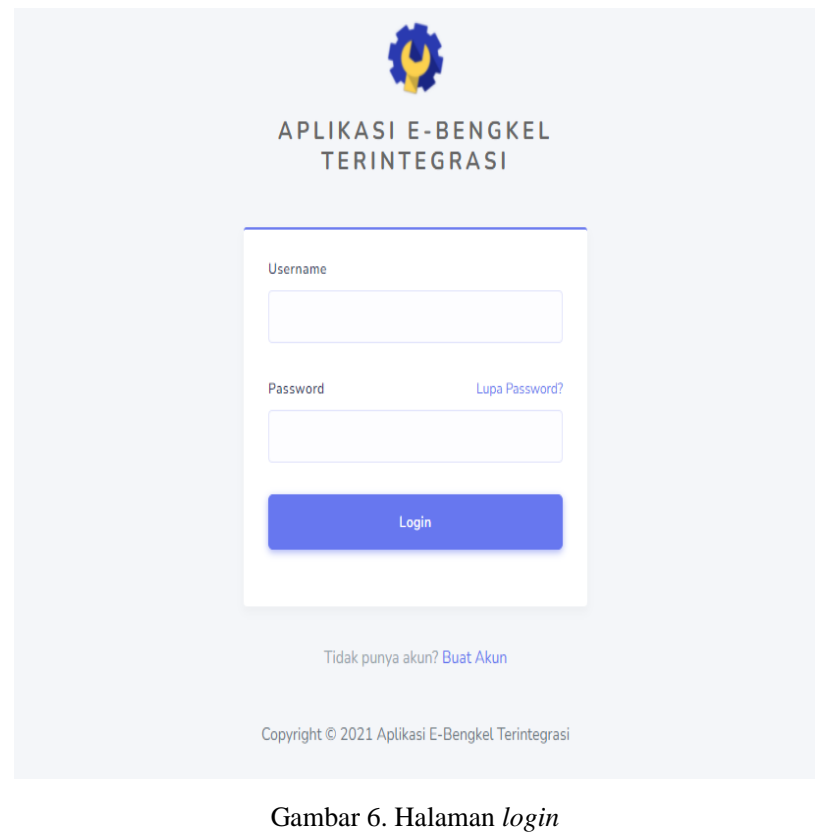

Gambar 6 merupakan halaman login, pengguna diminta untuk mengisi username dan password yang telah terdaftar untuk bisa login ke Aplikasi E-Bengkel Terintegrasi. 


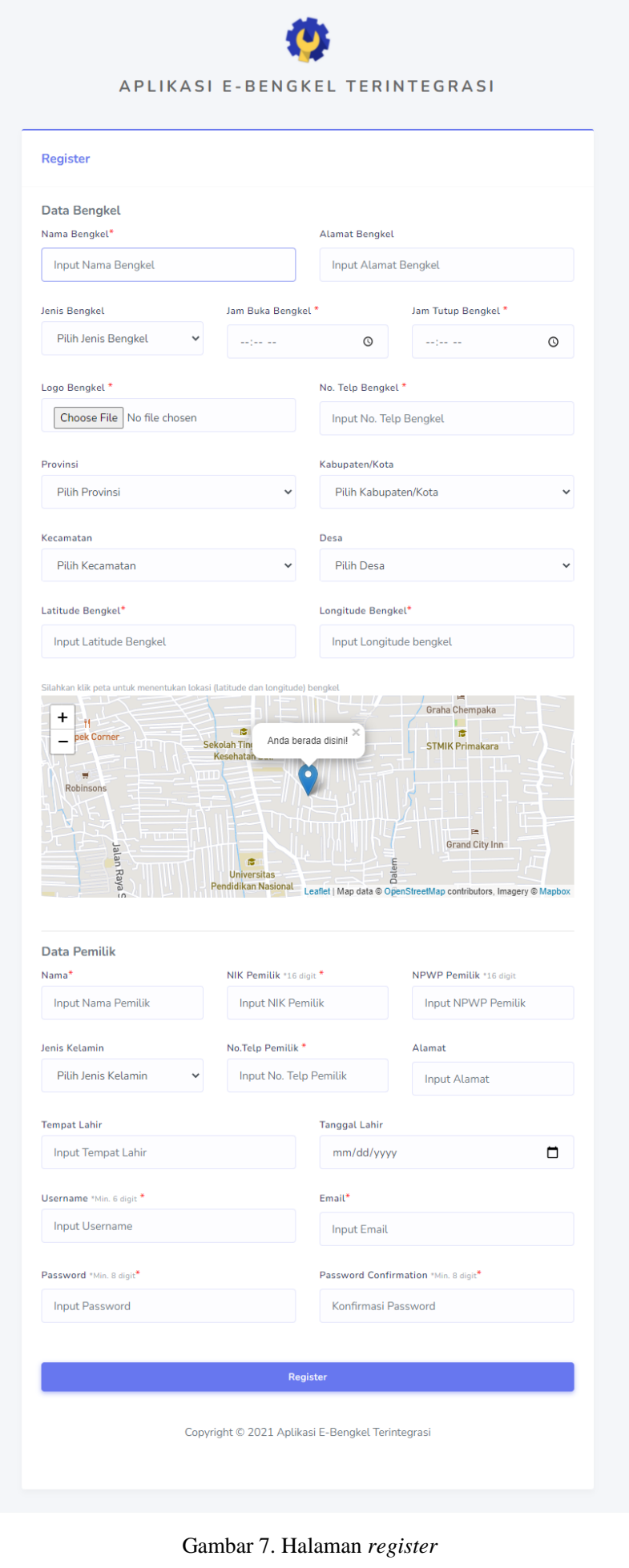

Gambar 7 merupakan halaman register. Pemilik bengkel melakukan input data bengkel dan data pemilik bengkel. Data bengkel berisi nama bengkel, alamat, jam buka, jam tutup, logo bengkel, nomor telepon, provinsi, kabupaten/kota, kecamatan, desa, latitude dan longitude bengkel. Data pemilik bengkel berisi nama pemilik, NIK pemilik, NPWP pemilik, jenis kelamin, no. telp pemilik, alamat, tempat tanggal lahir, username, email, password.

Pengguna
Input Formulir Pengguna
Nama Pegawai *
\begin{tabular}{ll}
\hline Pilin Pegawai & Email * \\
Input Username & Input Email \\
Password & \\
Input Password & $\square$ Konfirmasi Password \\
Pilih Aplikasi yang Tersedia! & $\square$ Aplikasi Front Office \\
& $\square$ Aplikasi Service Advisor \\
& $\square$ Aplikasi Service Instructor \\
& $\square$ Aplikasi Point of Sales \\
& $\square$ Aplikasi Gudang \\
& $\square$ Aplikasi Purchasing Accounting \\
& $\square$ Aplikasi Marketplace
\end{tabular}

Gambar 8. Tambah pengguna dan hak akses SSO

Gambar 8 merupakan tampilan formular menambah hak akses pengguna. Admin dapat menambahkan pengguna baru dengan akses yang telah ditetapkan pada halaman ini.

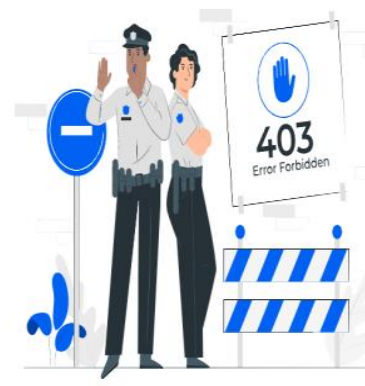

Anda tidak memiliki akses ke halaman ini.

— Kembalike Dashboard SSO

Gambar 9. Error 403 hak akses ditolak

Gambar 9 merupakan tampilan error 403 apabila hak akses pengguna ditolak oleh aplikasi. Contoh apabila pengguna dengan akses Aplikasi Front Office saja ingin mengakses bagian dari Aplikasi Service, maka Aplikasi Service tidak akan memberi akses dan halaman error 403 akan muncul. 


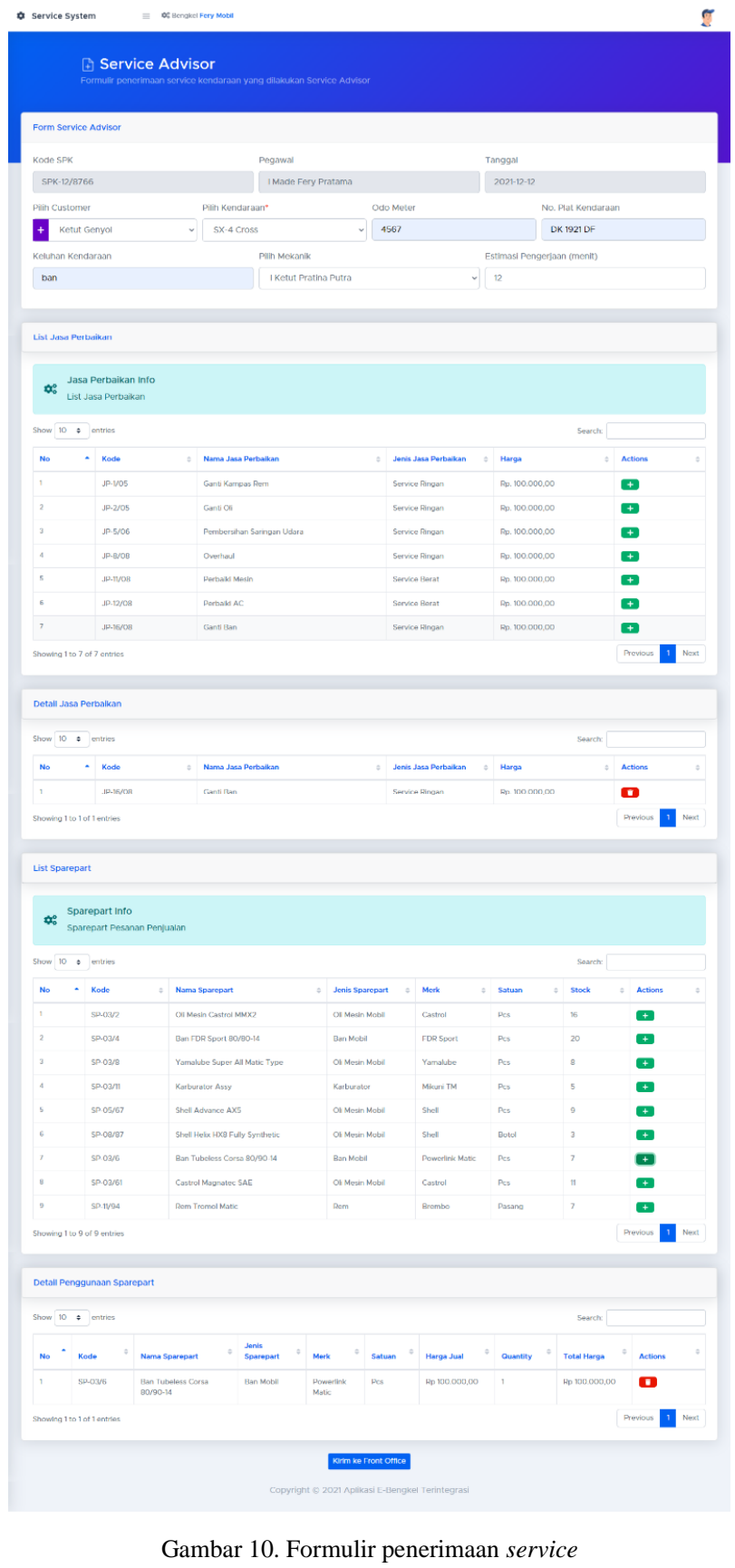

Gambar 10 merupakan tampilan penerimaan service. Petugas Service Advisor mengisi formular ini yang berisi tanggal, nama customer, kendaraan, odo meter, nomor plat kendaraan, keluhan kendaraan, mekanik, dan estimasi pengerjaan.

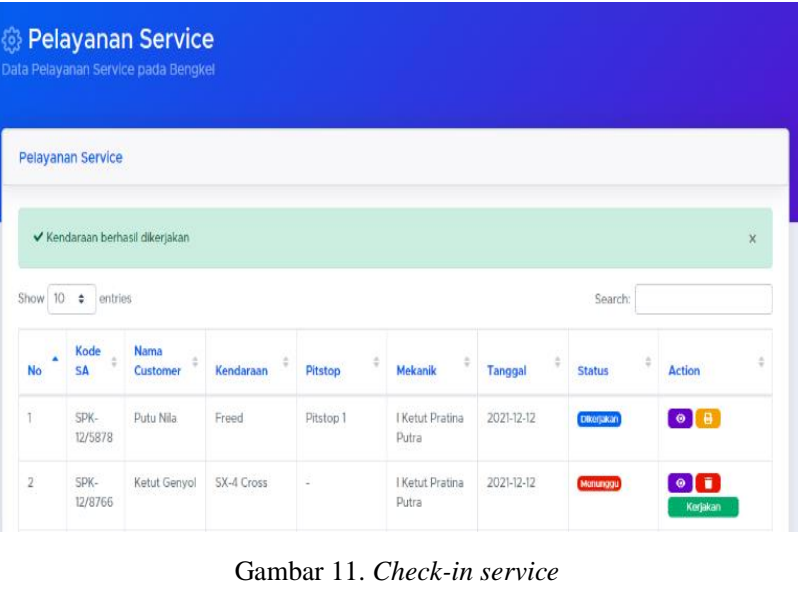

Gambar 11 merupakan tampilan check-in service. Admin Front Office dapat melakukan check-in service kendaraan yang sudah didaftarkan oleh Service Advisor. Admin Front Office melakukan check-in service dengan menekan button 'Kerjakan' dan mengubah status data dari yang sebelumnya 'menunggu' menjadi 'dikerjakan'.

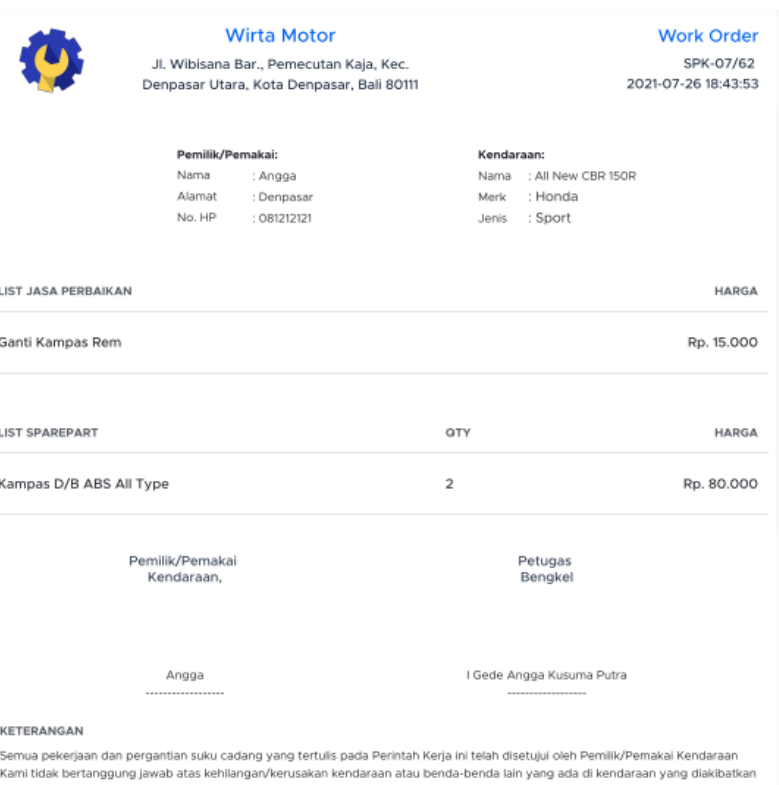

Gambar 12. Work order service

Gambar 12 merupakan tampilan work order service kendaraan. Work order ini dapat dicetak setalah admin Front Office melakukan check-in kendaraan. Work order ini berisi list jasa perbaikan dan list spare part yang digunakan untuk service kendaraan customer 


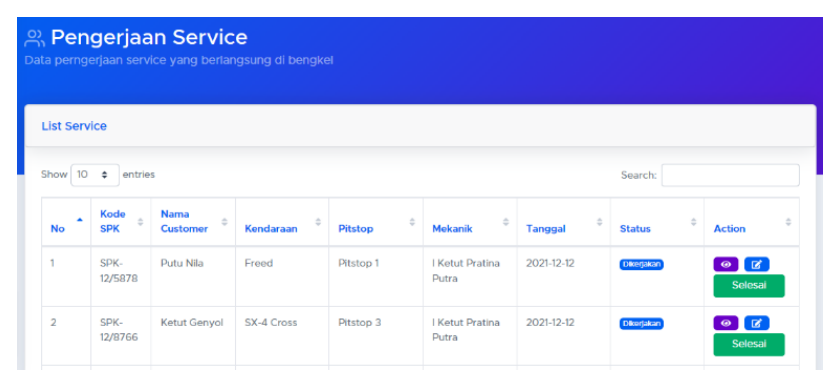

Gambar 13. Pengerjaan service

Gambar 13 merupakan tampilan halaman pengerjaan service kendaraan. Halaman ini dapat digunakan oleh admin Service Instructor untuk melakukan konfirmasi selesai pengerjaan service kendaraan.

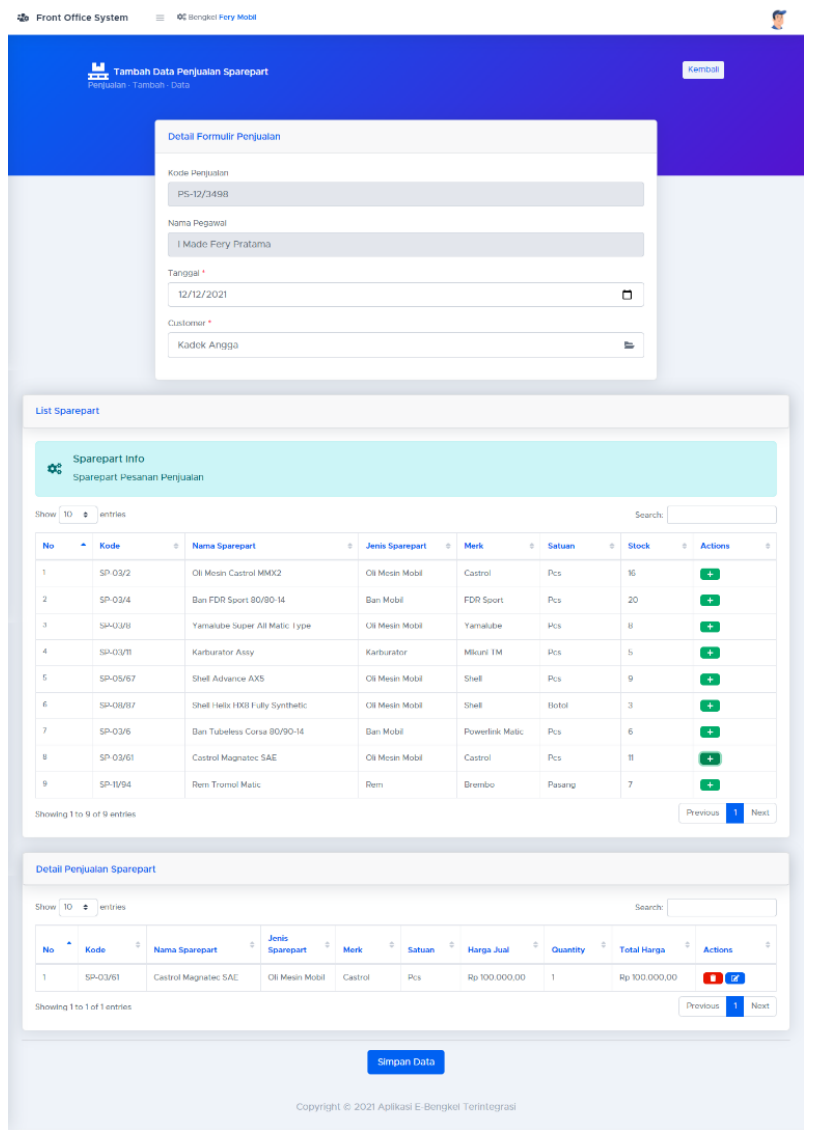

Gambar 14. Formulir penjualan spare part

Gambar 14 merupakan formulir untuk melayani penjualan spare part untuk customer. Admin Front Office diminta untuk mengisi formulir detail penjualan spare part yang berisi kode penjualan, nama pegawai, tanggal, customer, dan data spare part yang dibeli oleh pelanggan bengkel.
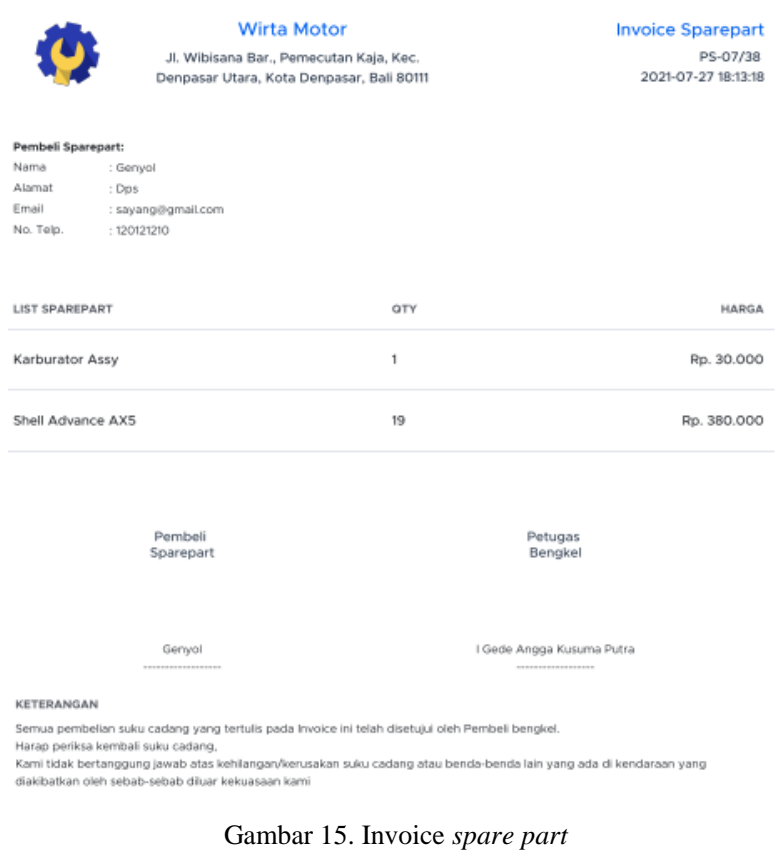

Gambar 15 merupakan tampilan invoice spare part yang dapat dicetak setelah admin Front Office mengisi data penjualan spare part. Invoice spare part tersebut berisi nama, quantity, dan harga dari spare part yang dibeli oleh pelanggan bengkel.

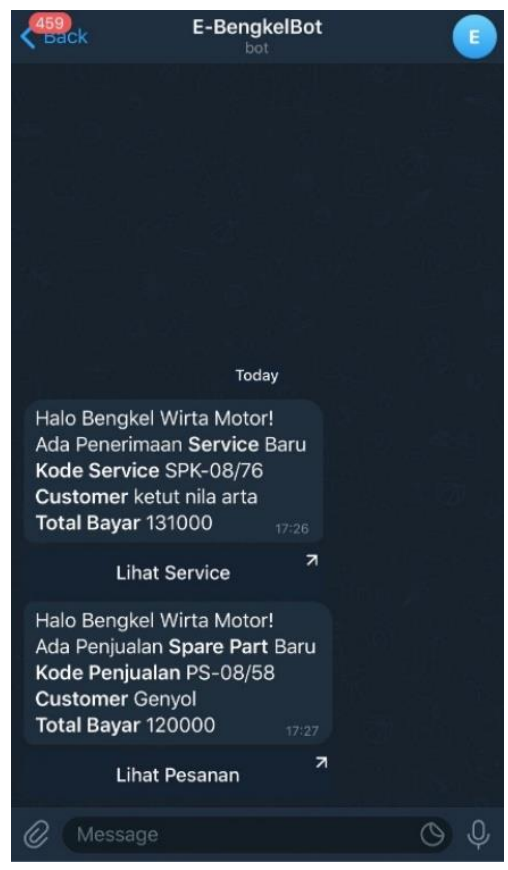

Gambar 16. Notifikasi MCA Telegram

Gambar 16 merupakan tampilan notifikasi dari chat Telegram. Notifikasi tersebut diterma oleh Pemilik bengkel setiap terdapat transaksi service atau transaksi spare part baru. 


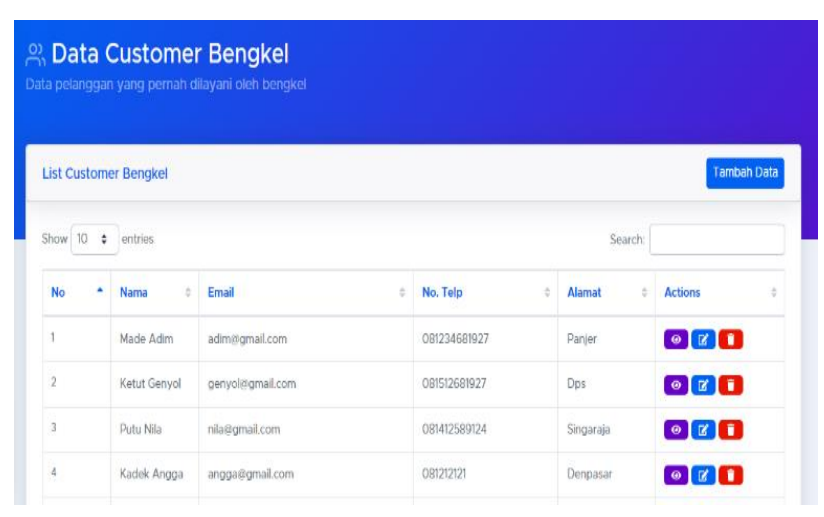

Gambar 17. Manajemen data customer

Gambar 17 merupakan tampilan manajemen data customer bengkel kendaraan. Admin Front Office dapat melakukan tambah, edit, dan delete data customer bengkel kendaraan.

\section{B. Pengujian Sistem}

Pengujian sistem dilakukan dengan menggunakan pengujian black-box. Pengujian black-box digunakan untuk menguji fungsionalitas dari sistem dengan mencoba fungsi dan menu yang disediakan oleh sistem informasi. Detail pengujian dapat dilihat pada tabel berikut.

TABEL II

Pengujian Metode Black-Box

\begin{tabular}{|c|c|c|c|c|}
\hline $\begin{array}{l}\mathbf{N} \\
\mathbf{0}\end{array}$ & $\begin{array}{l}\text { Fungsio } \\
\text { nal }\end{array}$ & Skenario & Hasil & Keterangan \\
\hline 1 & Register & $\begin{array}{l}\text { Pemilik bengkel } \\
\text { mengisi } \\
\text { formular data } \\
\text { bengkel dan } \\
\text { data pemilik }\end{array}$ & $\begin{array}{l}\text { Pemilik } \\
\text { berhasil } \\
\text { masuk ke } \\
\text { halaman } \\
\text { Dashboard } \\
\text { Single Sign- } \\
\text { On }\end{array}$ & Sesuai \\
\hline 2 & $\begin{array}{l}\text { Login } \\
\text { Data } \\
\text { Benar }\end{array}$ & $\begin{array}{l}\text { Pengguna } \\
\text { memasukkan } \\
\text { username dan } \\
\text { password benar }\end{array}$ & $\begin{array}{l}\text { Pengguna } \\
\text { berhasil } \\
\text { masuk ke } \\
\text { sistem } \\
\text { informasi } \\
\end{array}$ & Sesuai \\
\hline 3 & $\begin{array}{l}\text { Login } \\
\text { Data } \\
\text { Salah }\end{array}$ & $\begin{array}{l}\text { Pengguna } \\
\text { memasukkan } \\
\text { username dan } \\
\text { password salah }\end{array}$ & $\begin{array}{l}\text { Sistem } \\
\text { menampil- } \\
\text { kan pesan } \\
\text { error. } \\
\text { Pengguna } \\
\text { gagal masuk } \\
\text { ke sistem } \\
\text { informasi }\end{array}$ & Sesuai \\
\hline 4 & $\begin{array}{l}\text { Tambah } \\
\text { data } \\
\text { pengguna }\end{array}$ & $\begin{array}{l}\text { Admin memilih } \\
\text { button 'Tambah } \\
\text { Pengguna, } \\
\text { kemudian } \\
\text { mengisi } \\
\text { formulir dan } \\
\text { klik button } \\
\text { 'Save' }\end{array}$ & $\begin{array}{l}\text { Sistem } \\
\text { menyimpan } \\
\text { data } \\
\text { pengguna } \\
\text { pada } \\
\text { database }\end{array}$ & Sesuai \\
\hline 5 & $\begin{array}{l}\text { Ubah } \\
\text { data } \\
\text { pengguna }\end{array}$ & $\begin{array}{l}\text { Admin memilih } \\
\text { button 'Edit', } \\
\text { kemudian } \\
\text { mengubah data } \\
\text { dan klik button } \\
\text { 'Save' }\end{array}$ & $\begin{array}{l}\text { Sistem } \\
\text { menyimpan } \\
\text { perubahan } \\
\text { data } \\
\text { pengguna } \\
\text { pada } \\
\text { database } \\
\end{array}$ & Sesuai \\
\hline
\end{tabular}

\begin{tabular}{|c|c|c|c|c|}
\hline $\begin{array}{l}\mathbf{N} \\
\mathbf{0}\end{array}$ & $\begin{array}{l}\text { Fungsio } \\
\text { nal }\end{array}$ & Skenario & Hasil & Keterangan \\
\hline 6 & $\begin{array}{l}\text { Hapus } \\
\text { data } \\
\text { pengguna }\end{array}$ & $\begin{array}{l}\text { Admin memilih } \\
\text { button 'Delete', } \\
\text { kemudian } \\
\text { menghapus data } \\
\text { pengguna dan } \\
\text { klik button } \\
\text { 'Save' }\end{array}$ & $\begin{array}{l}\text { Sistem } \\
\text { menghapus } \\
\text { data } \\
\text { pengguna } \\
\text { pada } \\
\text { database }\end{array}$ & Sesuai \\
\hline 7 & $\begin{array}{l}\text { Hak } \\
\text { Akses } \\
\text { Single } \\
\text { Sign-On }\end{array}$ & $\begin{array}{l}\text { Admin Front } \\
\text { Office bengkel } \\
\text { mengakses } \\
\text { halaman Admin } \\
\text { layanan bengkel }\end{array}$ & $\begin{array}{l}\text { Sistem } \\
\text { mengarah-kan } \\
\text { ke halaman } \\
\text { error 403, } \\
\text { karena admin } \\
\text { Front Office } \\
\text { tidak } \\
\text { memiliki } \\
\text { akses }\end{array}$ & Sesuai \\
\hline 8 & $\begin{array}{l}\text { Tambah } \\
\text { data } \\
\text { penerima } \\
\text { an } \\
\text { service } \\
\text { kendaraa } \\
\text { n }\end{array}$ & $\begin{array}{l}\text { Admin } \\
\text { menambah-kan } \\
\text { data service } \\
\text { kendaraan pada } \\
\text { halaman form } \\
\text { Service Advisor }\end{array}$ & $\begin{array}{l}\text { Sistem } \\
\text { menyimpan } \\
\text { data service } \\
\text { kendaraan } \\
\text { pada } \\
\text { database }\end{array}$ & Sesuai \\
\hline 9 & $\begin{array}{l}\text { Tambah } \\
\text { data } \\
\text { check-in } \\
\text { service }\end{array}$ & $\begin{array}{l}\text { Admin memilih } \\
\text { button } \\
\text { 'Kerjakan' dan } \\
\text { kendaraan } \\
\text { mulai } \\
\text { dikerjakan } \\
\end{array}$ & $\begin{array}{l}\text { Sistem } \\
\text { mengubah } \\
\text { status service } \\
\text { kendaraan } \\
\text { menjadi } \\
\text { 'dikerja-kan' } \\
\end{array}$ & Sesuai \\
\hline 10 & $\begin{array}{l}\text { Cetak } \\
\text { work } \\
\text { order } \\
\text { service }\end{array}$ & $\begin{array}{l}\text { Admin memilih } \\
\text { button 'Print } \\
\text { Work Order' }\end{array}$ & $\begin{array}{l}\text { Sistem } \\
\text { melakukan } \\
\text { print work } \\
\text { order }\end{array}$ & Sesuai \\
\hline 11 & $\begin{array}{l}\text { Tambah } \\
\text { data } \\
\text { penjualan } \\
\text { spare } \\
\text { part }\end{array}$ & $\begin{array}{l}\text { Admin } \\
\text { menambah-kan } \\
\text { data pada form } \\
\text { penjualan spare } \\
\text { part }\end{array}$ & $\begin{array}{l}\text { Sistem } \\
\text { menyimpan } \\
\text { data } \\
\text { penjualan } \\
\text { spare part } \\
\text { pada } \\
\text { database } \\
\end{array}$ & Sesuai \\
\hline 11 & $\begin{array}{l}\text { Cetak } \\
\text { invoice } \\
\text { spare } \\
\text { part }\end{array}$ & $\begin{array}{l}\text { Admin memilih } \\
\text { button 'Print } \\
\text { Invoice' }\end{array}$ & $\begin{array}{l}\text { Sistem } \\
\text { melakukan } \\
\text { print invoice } \\
\text { spare part }\end{array}$ & Sesuai \\
\hline 12 & $\begin{array}{l}\text { Menamb } \\
\text { ah data } \\
\text { customer }\end{array}$ & $\begin{array}{l}\text { Admin memilih } \\
\text { button 'Tambah } \\
\text { Customer', } \\
\text { kemudian } \\
\text { mengisi } \\
\text { formulir dan } \\
\text { klik button } \\
\text { 'Save' }\end{array}$ & $\begin{array}{l}\text { Sistem } \\
\text { menyimpan } \\
\text { data customer } \\
\text { pada } \\
\text { database }\end{array}$ & Sesuai \\
\hline 13 & $\begin{array}{l}\text { Ubah } \\
\text { data } \\
\text { customer }\end{array}$ & $\begin{array}{l}\text { Admin memilih } \\
\text { button 'Edit', } \\
\text { kemudian } \\
\text { mengubah data } \\
\text { dan klik button } \\
\text { 'Save' }\end{array}$ & $\begin{array}{l}\text { Sistem } \\
\text { menyimpan } \\
\text { perubahan } \\
\text { data customer } \\
\text { pada } \\
\text { database }\end{array}$ & Sesuai \\
\hline 14 & $\begin{array}{l}\text { Hapus } \\
\text { data } \\
\text { customer }\end{array}$ & $\begin{array}{l}\text { Admin memilih } \\
\text { button 'Delete', } \\
\text { kemudian } \\
\text { menghapus data } \\
\text { dan klik button } \\
\text { 'Save' }\end{array}$ & $\begin{array}{l}\text { Sistem } \\
\text { menghapus } \\
\text { data customer } \\
\text { pada } \\
\text { database }\end{array}$ & Sesuai \\
\hline 15 & $\begin{array}{l}\text { Notifikas } \\
\text { i } \\
\text { Telegram } \\
\text { penerima } \\
\text { an }\end{array}$ & $\begin{array}{l}\text { Tambah data } \\
\text { service }\end{array}$ & $\begin{array}{l}\text { Sistem } \\
\text { mengirimkan } \\
\text { notifikasi } \\
\text { penerimaan } \\
\text { service baru }\end{array}$ & Sesuai \\
\hline
\end{tabular}




\begin{tabular}{|l|l|l|l|l|}
\hline $\begin{array}{l}\text { N } \\
\text { o }\end{array}$ & $\begin{array}{l}\text { Fungsio } \\
\text { nal }\end{array}$ & Skenario & Hasil & Keterangan \\
\hline & $\begin{array}{l}\text { service } \\
\text { baru }\end{array}$ & & $\begin{array}{l}\text { melalui MCA } \\
\text { Telegram }\end{array}$ & \\
\hline 16 & $\begin{array}{l}\text { Notifikas } \\
\text { i }\end{array}$ & $\begin{array}{l}\text { Tambah data } \\
\text { penjualan spare }\end{array}$ & $\begin{array}{l}\text { Sistem } \\
\text { mengirimkan } \\
\text { notifikasi }\end{array}$ & Sesuai \\
& $\begin{array}{l}\text { Telegram } \\
\text { penjualan }\end{array}$ & part & penjualan & \\
& spare part \\
& spare & & \\
& part baru & & MCA & \\
& & & Telegram & \\
& & & & \\
\hline
\end{tabular}

\section{Komparasi Sistem}

Komparasi sistem merupakan proses yang dilakukan untuk membandingkan fitur-fitur Sistem E-Bengkel terintegrasi dengan sistem informasi manajemen bengkel lainnya. Adapun sistem yang dibandingkan yaitu Sistem EBengkel terintegrasi dengan SIM Bengkel karya Audrilia, dkk[7] dan SIM Bengkel karya Winardi, dkk[9].

TABEL III

KOMPARASI SISTEM

\begin{tabular}{|c|c|c|c|c|}
\hline No & Nama Sistem & Fit & & Platform \\
\hline 1 & $\begin{array}{l}\text { Sistem E- } \\
\text { Bengkel } \\
\text { Terintegrasi } \\
\text { (Single Sign- } \\
\text { On, Front } \\
\text { Office, dan } \\
\text { Layanan) }\end{array}$ & 1) & $\begin{array}{l}\text { Menggunakan } \\
\text { penerapan Model } \\
\text { Single Sign-On } \\
\text { Manajemen data } \\
\text { customer dan spare } \\
\text { part } \\
\text { Dapat melakukan } \\
\text { penerimaan service } \\
\text { kendaraan } \\
\text { Dapat melakukan } \\
\text { check-in kendaraan } \\
\text { Dapat melakukan } \\
\text { pengerjaan service } \\
\text { kendaraan } \\
\text { Dapat melakukan } \\
\text { cetak work order } \\
\text { service } \\
\text { Dapat melakukan } \\
\text { cetak invoice } \\
\text { penjualan spare part. } \\
\text { Dapat mengirimkan } \\
\text { notifikasi MCA } \\
\text { Telegram }\end{array}$ & Web \\
\hline 2 & $\begin{array}{l}\text { Sistem } \\
\text { Informasi } \\
\text { Manajemen } \\
\text { Bengkel } \\
\text { Anugrah }\end{array}$ & $\begin{array}{l}\text { 3) } \\
4) \\
5)\end{array}$ & $\begin{array}{l}\text { Manajemen jasa } \\
\text { service } \\
\text { Manajemen spare } \\
\text { part } \\
\text { Manajemen mekanik } \\
\text { Grafik penjualan } \\
\text { Grafik kinerja } \\
\text { mekanik } \\
\text { Grafik service } \\
\text { Laporan data } \\
\text { pelanggan dan } \\
\text { pengadaan }\end{array}$ & Web \\
\hline 3 & $\begin{array}{l}\text { Sistem } \\
\text { Informasi } \\
\text { Manajemen } \\
\text { Bengkel CV. } \\
\text { Anugrah Bogor }\end{array}$ & & $\begin{array}{l}\text { Transaksi Service } \\
\text { Manajemen Data } \\
\text { Barang } \\
\text { Manajemen Data } \\
\text { Pegawai } \\
\text { Manajemen Data } \\
\text { Pelanggan }\end{array}$ & Web \\
\hline
\end{tabular}

Kesimpulan yang dapat diambil dari penelitian penelitian Penerapan Model Single Sign-On dengan Sistem Front Office dan Sistem Layanan pada Sistem E-Bengkel Terintegrasi yaitu Sistem E-Bengkel ini dibuat dengan menyesuaikan bisnis proses suatu Front Office dan Layanan pada bengkel kendaraan. Sistem Front Office pada bengkel merupakan bagian yang menangani manajemen data customer bengkel, penjualan spare part, pembuatan invoice spare part, dan check-in service. Sistem Layanan pada bengkel merupakan bagian yang menangani proses penerimaan dan pengerjaan service kendaraan customer.

Model Single Sign-On pada Sistem E-Bengkel ini dapat melakukan autentikasi, otorisasi, dan manajemen pengguna. Autentikasi untuk melakukan validasi credentials (username dan password) pengguna dan menetapkan identitas pengguna. Otorisasi untuk melakukan pembatasan hak akses pada pengguna. Manajemen pengguna untuk melakukan administrasi (pembuatan, penghapusan, pembaruan) akun pengguna. Sistem E-Bengkel didukung dengan penerapan Multi-Channel Access (MCA) dalam bentuk notifikasi Telegram yang dapat diterima oleh Pemilik Bengkel setiap ada penerimaan service dan penjualan spare part baru. Sistem E-Bengkel ini dibuat menggunakan pengembangan SDLC (Sistem Development Life Cycle) dengan metode waterfall dan dibangun berbasis aplikasi web yang menggunakan bahasa HTML, CSS, Javascript, PHP, serta menggunakan MySQL sebagai DBMS (Database management sistem). Perancangan basis data pada Sistem E-Bengkel ini digambarkan melalu PDM (Physical Data Model). Pengujian pada sistem ini menggunakan metode black-box testing yang digunakan untuk menguji fungsionalitas dari sistem dengan mencoba fungsi dan menu yang disediakan oleh sistem informasi.

\section{UCAPAN TERIMA KASIH}

Ucapan terimakasih yang mendalam kepada Lembaga Penelitian dan Pengabdian Universitas Udayana, Bali yang melalui Dana DIPA PNBP pada Hibah Penelitian Produk Inovatif Udayana Tahun 2021 memberikan bantuan pembiayaan, sehingga bisa terselenggaranya penelitian ini.

\section{REFERENSI}

[1] B. P. Statistik, Perkembangan Jumlah Kendaraan Bermotor Menurut Jenis (Unit), 2017-2019. 2021.

[2] N. Heijmink, "Secure Single Sign-On A comparison of protocols" CCV \& Radboud University Nijmegen, 2015.

[3] G. Guntoro and M. Fikri, "Perancangan Aplikasi Single SignOn Menggunakan Autentikasi Gambar," Digital Zone: Jurnal Teknologi Informasi dan Komunikasi, vol. 9, no. 1, 2018.

[4] Z. Musliyana, T. Y. Arif, and R. Munadi, "Peningkatan Sistem Keamanan Autentikasi Single Sign On (SSO) Menggunakan Algoritma AES dan One-Time Password Studi Kasus: SSO Universitas Ubudiyah Indonesia," Jurnal Rekayasa Elektrika, vol. 12 , no. $1,2016$.

[5] Khanna Tiara, F. M. Putri, and H. Triyani, "Optimalisasi Single Sign On Untuk Meningkatkan Sistem Keamanan OJRS+," Technomedia Journal, vol. 1, no. 2, 2017.

[6] I. Putu, A. Eka, and D. Udayana, "Implementasi Dan Analisis Single Sign On Pada Sistem Informasi Universitas Udayana," Seminar Nasional Teknologi Informasi dan Multimedia, 2016. 
[7] M. Audrilia and A. Budiman, "Perancangan Sistem Informasi Manajemen Bengkel Berbasis Web (Studi Kasus: Bengkel Anugrah)," Jurnal Madani : Ilmu Pengetahuan, Teknologi, dan Humaniora, vol. 3, no. 1, 2020.

[8] R. R. M. Salim, "Rancang Bangun Sistem Informasi Bengkel Untuk Pengelolaan Transaksi Dan Peningkatan Pelayanan Kepada Pelanggan," Jurnal Ilmiah Matrik, vol. 21, no. 3, 2019.

[9] A. Winardi, I. Farida, D. Hariyanto, and A. Bsi Bogor, "Rancang Bangun Sistem Informasi Manajemen Bengkel (Studi Kasus: CV. Anugrah Bogor)," IJSE - Indonesian Journal on Software Engineering, vol. 3, no. 2, 2017.

[10] I. G. N. A. Widhiananda, I. M. Arsa Suyadnya, and K. Oka Saputra, "Rancang Bangun Aplikasi Reservasi Service Untuk Bengkel Sepeda Motor Berbasis Web," E-Journal SPEKTRUM, vol. 4, no. 2, 2018.

[11] D. P. Githa and N. P. Sutramiani, "Rancang Bangun Sistem Informasi Bengkel Vespa di Denpasar," SINTECH (Science and Information Technology) Journal, vol. 1, no. 1, 2018.

[12] H. Jogiyanto, Analisa dan Desain Sistem Informasi: Pendekatan Terstruktur Teori dan Praktik Aplikasi Bisnis. Yogyakarta: Andi, 2005.

[13] E. Faja Ripanti, H. A. Oramahi, and J. H. Hadari Nawawi, "Rancangan Sistem Informasi Pengelolaan Audit Mutu Internal (AMI) Perguruan Tinggi." JEPIN (Jurnal Edukasi dan Penelitian Informatika, vol. 7, no. 1, 2021

[14] O. A. Permata, K. Amiroh, A. A. Rullah, "Pengembangan Sistem Penukaran Tiket Suroboyo Bus Melalui Digitalisasi Pencatatan Penukaran Sampah Berbasis Android. "JEPIN (Jurnal Edukasi dan Penelitian Informatika, vol. 7, no. 1, 2021.

[15] M. Y. P. Mahendra, I. N. Piarsa, and D. Putra Githa, "Geographic Information System of Public Complaint Testing Based On Mobile Web (Public Complaint)," Lontar Komputer : Jurnal Ilmiah Teknologi Informasi, vol. 9, no. 2, 2018.

[16] N. D. A. Muhamad Nasihin, Yulia, "Sistem Informasi AKUNTER ( Akuntansi Terpadu ) Berbasis Web Sebagai Pengelolaan Transaksi Keuangan Pada Mutiara Laundry," JEPIN (Jurnal Edukasi dan Penelitian Informatika, vol. 6, no. 3,2020

[17] Aminudin, "Implementasi Single Sign On (SSO) Untuk Mendukung Interaktivitas Aplikasi E-Commerce Menggunakan Protocol Oauth," JURNAL GAMMA, vol. 10, no. 1, 2016.

[18] P. Gamaswara, A. A. . O. Sudana, and N. M. I. M. Mandenni, "Perancangan Sistem Informasi Manajemen Modul Layanan Pada Rumah Sakit," Lontar Komputer : Jurnal Ilmiah Teknologi Informasi, vol. 6, no. 3, 2015. 